\title{
Sustainable Development Strategy Of Domestic Waste Infrastructure In The City Of Surakarta
}

\author{
Arya Rezagama ${ }^{1, *}$, Purwono $^{1}$ and Verika Damayanti $^{1}$ \\ ${ }^{1}$ Department of Environmental Engineering, Faculty of Engineering, Diponegoro University, Semarang - Indonesia
}

\begin{abstract}
Shifting from traditional system to large, centralised infrastructure domestic waste is widely complex challenge. Most of fhe sanitary system on household in Surakarta use on site septictank, 17\% sewerage system reached and $16,0 \%$ stll open defecations. Sanitation development sustained aims to develop policy and strategies waste management domestic Surakarta in the long term (20 years). The projection use quantitative method and institutional condition approach by SWOT analysis. Surakarta City get priority sanitation urban planning from Indonesian government in Presiden Joko Widodo era. The domestic waste management systems that is Surakarta divided into system on-site and system off site. Waste Water Treatment Plant (WWTP) mojosongo, WWTP pucangsawit and WWTP Semanggi will be developed to treat $30 \%$ domestic waste of Surakarta Residence. While on-site system will are served $70 \%$ residence by service programs Regular Cleaning Septictank. The toughest challenge is how to increase community participation in waste management and improve the company"s financial condition. Sanitation sustainable development is go ing to happen if supported by facility development also good, institutional development, the arrangement that oversees, and the public participation.
\end{abstract}

\section{Introduction}

Sustainable Development Goals (SDGs) has placed availability and sustainable management of water and sanitation as the sixth goal. Open defecation were practiced by 892 million people (12 per cent of the global population), continues to pose a serious health risk[1]. Large cities in the world obtain $78 \pm 3 \%$ of their water from surface sources, some of which are far away: cumulatively, large cities moved 504 billion liters a day $\left(184 \mathrm{~km}^{3} \mathrm{yr}^{-1}\right)$ a distance of $27,000 \pm 3800 \mathrm{~km}$ [2]. Urban growth like in Indonesia Cities is increasing the demand for freshwater resources, hampering efforts to assess the sewerage can causes of urban water stress.

The high level of domestic pollution will impact significantly to the quality of the health of people living along flood plains such in Surakarta area [3]. The development of sanitation has an important function as it pertains to health, lifestyle and environmental conditions that can provide comfort in daily life. This problem is the responsibility of the Indonesia government and society. Evaluation of wastewater management in developing countries is important, where sanitation conditions are usually poor[4]. Indonesia is developing countries with a backlog in achieving targets for the implementation of wastewater collection, treatment and recovery systems [5]. The Challenge of development waste water treatment in developing country is very complex. Infrastructure still weak and human resources is limited. In other side, people still get bad habits throw rubbish into the river. We will found easily trash so much along river. Sometimes trash can block the water flow and cause flood. Hence, waste water treatment need to be addressed precisely and sustainable, so the water

\footnotetext{
*orresponding author: arya $\mathrm{tl} @$ ft.undip.ac.id
}

out safe into a body of water for public health and the environment.

A number experiment in qualitative or case study design research support implementation sustainable development infrastructure in domestic waste is still rare in Indonesia. However there are few studies using case study in Indonesia city that have complex challenge, social rejection, and developing country problem. There has been limited use of studies such consistency of regulation government, weak of implementation and complex relation of government department. The present study will focus describe detail strategy to implement sustainable infrastructure in domestic waste. The current study aims to determine total amount domestic waste produced, describe strategy how to treat waste by system on site and off site and strategy planning to implement.

This paper empirically examines the governance needs of strategy to develop domestic waste infrastructure, using Indonesian water sector and the challenges it faces as a rich source of insight. Derived from extensive qualitative research drawing on the projection waste water produce, the paper tests the current governance approaches considered suitable for sustainable infrastructure. Finally key questions and challenges arising from this research are identified

\section{Methods}

Surakarta is one of the cities in Central Java with total area of $44.4 \mathrm{~km} 2$, with a population of 512,226 inhabitants, with a density of 11,631 people $/ \mathrm{km}^{2}[6]$. The research methodology carried out in several phases includes preparation, data collection, processing and data 
analysis, conclusion. Primary data collection is done by direct observation in the field, calculation of water source pipeline system and WWTP. While the secondary data obtained through interviews, documents from relevant respondents.

First, calculate population growth projection with comparative study of regression analysis of linear, exponential and logarithmic statistical models. Data input uses the population for the previous ten years. The method projection base on Regression modeling strategies: with applications to linear models, logistic and ordinal regression, and survival analysis book. Projection Demand Wastewater used to determine the amount of water demand for the next 20 years (20162030)

Second, analysis domestic waste water existing condition use Strengths Weaknesses Opportunities Threats Matrix. SWOT analysis aims to identify the key internal and external factors seen as important to achieving an objective. SWOT Analysis is instrumental in strategy formulation and selection. It is a strong tool, but it involves a great subjective element. It is best when used as a guide, and not as a prescription. The method analysis base on SWOT Analysis. Idea, Methodology And A Practical Approach [7]. Limited resources and investment requires strategy to make prior planning. The priority use scoring method base on aspect of health, infrastructure, pollutant load, and environmental condition.

On site system is taken into account with the projections by 2020 will be served by $70 \%$ using the method of Fecal Sludge Services scheduled and declined to $40 \%$ in 2035 . Waste water is waste water derived from the households are feces human waste of neighborhood (real estate), restaurants, office, commercial, the apartment and dormitory. The domestic wastewater needs to treat before discharge to environment. Total wastewater load is calculated using a formula to use a formula as follows $80 \%$ of water supply consumption. The total demand water supply meet water Work Surakarta City. When urban village serviced by the pipe waste water service means the area included in the recommendations priority off-site system, while areas have not passed by a pipe service included in onsite service system.

\section{Result And Discussion}

In the UN in 2017 report said 600 million people still used a "limited" service an improved facility shared with other households. 2.9 billion people used a "safely managed" sanitation service, defined as a basic facility that safely disposes of human waste and another 2.1 billion people used a "basic" service-an improved facility that is not shared [1]. Household waste water or dirty water from community activities Surakarta ranks highest in the discharge of about $89 \%$, and then $11 \%$ of industry and hospitals [3].

Waste water infrastructure is one of the most important socio-technical systems underpinning the development and functioning of modern cities like in developing countries [8]. Quality of river has socioeconomic relationship of water-life quality. It can be measured by several indicators like communities and population access to water sources, water influence on the health of the population, water use, water quality, public perception on the supply of water[9].

Base on SDGs target, Indonesian government have target to reduce lack sanitation access until $0 \%$ in 2019. The urban poor are also highly affected by the environmental problems such as inadequate urban services (water, sanitation) and poor housing conditions. Surakarta City get priority sanitation urban planning from Indonesian government in Presiden Joko Widodo era. The city of Surakarta in the province of Central Java has emerged as a very prominent and celebrated case of policy innovation within and beyond Indonesia[10]. Several program to reduce open defecation to river had been doing. "Bedah Kampung" Program was Relocated people in Solo began in 2011 and built upon the existing interest of the municipality in conserving and revitalizing a traditional waterfront market. Program has contributed to sustainable housing development of the area [11]. The relocation of squatters notably from the banks of the Bengawan Solo River to self-built permanent new homes partly subsidized by the city government and complete with property rights was not, a prelude to lucrative private sector development but instead oriented towards the creation of new civic spaces within the city [10].

Waste water services in the city of Surakarta, should be developed in order to be able to handle the waste water load caused by everyday household activities, commercial (commercial) activities, and social events. Appropriate time span of planning in this master plan, the calculation of the load of waste water services, consisting of the total waste water discharge and the organic load, will be performed for 20 years into the future (2016 - 2035). Base on city environment report, A half river in Surakarta City was polluted by domestic waste in middle risk. The value of COD rise until 80 $\mathrm{mg} / \mathrm{l}$ and even more than $100 \mathrm{mg} / \mathrm{l}$ in several places. The colour of water look dark, smelly, and high turbidity. The impacts of discharges waste water directly on aquatic ecosystems include eutrophication, deoxygenation, fish kills and accumulation of toxic metals and compounds in sediments, plants, fish and other animals[8].

The Surakarta waste water management plan is prioritized in the future using offsite systems. Service levels for offsite systems are designed to increase from year to year. As for the system onsite as much as possible maintained at the maximum sludge waste as 250 $\mathrm{m}^{3} /$ day on the target service $70 \%$ population by 2020 . Besides the offsite system is a system that has advantages in controlling the quality of waste water. So that waste water discharged into the environment / river body will be more maintained quality.

On site system uses the septic tank that located in every house. Onsite systems in Surakarta city has grown to include Septic tank, Communal households WWTP, industry WWTP. Future planning, all onsite household will become a customer of sludge service regularly 
program. Every 3 year, costumer of water work will automatically maintain to be waste water service. Sludge in septic tank will be drained by truck and deliver to domestic sludge handling unit. The location is on side of final disposal Putri Cempo. Unit process sludge handling consist of imhoff tank, anaerobic pond, facultative pond, maturasi pond and sludge drying bed.

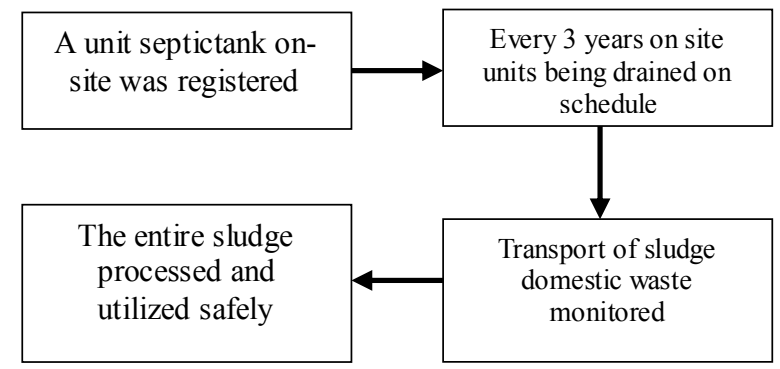

Fig. 1 Service Flow of sludge service regular program

Communal system, area system, and the system of the region need waste water treatment facilities in order to lower organic compounds and solids (suspended solids) that is contained in waste water until it reaches the target processed (effluent) desired. Installation of some more sophisticated designed also capable of lowering the polluter other content, as the nutrient (a compound of nitrogen and phosphate). Installation of water for domestic waste almost always apply biological process to lower the womb of organic compounds, both in the aerobic, anaerobic, and facultative. The cost estimates for the assessment of required wastewater investment and operational budgets in the planning process depend on land prices and revenues from recovered resources that were varied. It showed that the effect of high land prices on land intensive WWT systems have a major impact[5]

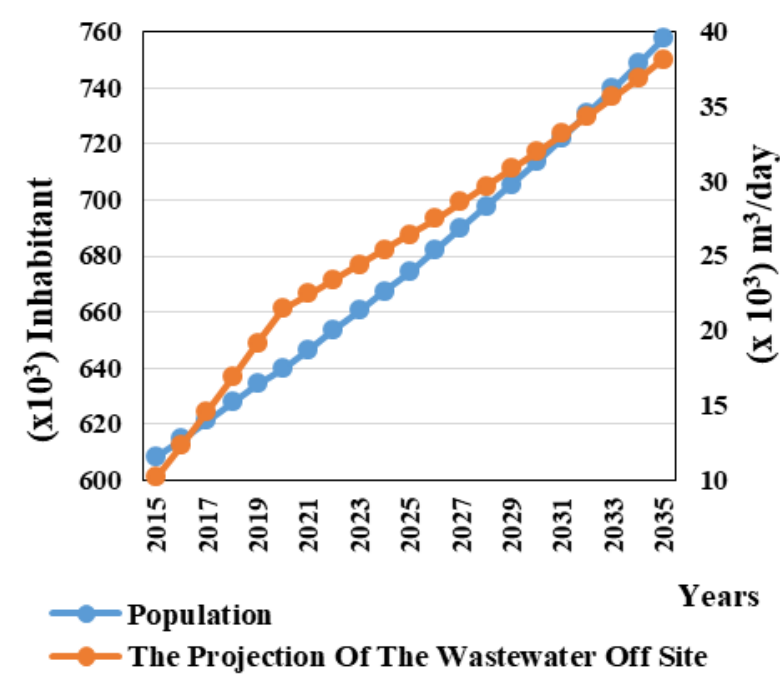

Fig. 2 The Projection Of The Wastewater Off Site

Centralized system or off site system is a system where the waste water from the whole area of service collected in collectors riol, which then streamed into the city riol to processing facility and thrown into a body of water recipients. Now, All WWTP was serving 14,000 connection, or less than $15 \%$ from Surakarta Population. The plan targeted offsite system service levels can serve $30 \%$ in total population in the year 2019 . It will then be increased $41 \%$ in 2035 . Domestic waste water services in the city of Surakarta was divided into 3 zones. In the Southern area there are WWTP Semanggi with capacity of $60 \mathrm{l} / \mathrm{s}$ serving about 8928 connection. In the central there are WWTP Pucangsawit 401 / s serving about 576 connection. And in northern area there are WWTP mojosongo with capacity of $501 / \mathrm{dt}$ and WWTP mojosongo with capacity $601 /$ dt serving 5420 connection. Offsite system development plan starting from Enhancing the capacity of waste treatment Installations. Perform optimization of the WWTP mojosongo from $50 \mathrm{l} / \mathrm{sec}$ to $70 \mathrm{l} / \mathrm{sec}$. build capacity with 2 WWTP Semanggi 100 1/sec. at this stage it also needs revamping and infrastructure, institutional, regulatory, community participation and dissemination Governments against the system.

The second phase target wastewater services city of Surakarta is $34 \%$ off site system of 297 1/sec with 38,216 Household. At this stage it is expected Surakarta sanitation can be increased with reduced waste in rivers, as well as the absence of households dumping waste water without being processed.

The third phase wastewater services target the city of Surakarta is $37 \%$ off site system of $342 \mathrm{l} / \mathrm{sec}$ with $43,994 \mathrm{KK}$. At this stage are targeted over the function of water quality to be well marked with the development of fish endemic to the river that is an indicator of good water. In addition to that obtained in ground water quality are not contaminated by the bacteria e-coli. The fourth stage waste water services target city of Surakarta is $41 \%$ off site system of $403 \mathrm{l} / \mathrm{sec}$ with $51,763 \mathrm{KK}$. In addition to improving service levels, at this stage it is also targeting the improvement quality of service by using the latest technology. The number household connection of sewer will improve the quality of water river [12].

In other side, projection waste water on site system of waste water are on the site in 2015 - 2019 increase very rapidly. But in the year 2020 - 2035 the resulting fecal discharge tends to be reduced. However by the year 2020 - 2035 discharge the black water which are produced tend to be lacking. This is due to the increase of the population of the system on the site will be maintained at influence of $250 \mathrm{~m}^{3} /$ day starting from the year 2020 - 2035 and the addition of residents will be on point with the system of the site. In future, capacity of domestic sludge handling unit reaches $250 \mathrm{~m}^{3} /$ day are still far from enough because the condition woke up now only $90 \mathrm{~m}^{3} /$ day.

There are two main reasons the need for the development of the sewerage system, such as: first meanwhile residential environment, and the degree of human health and to achieve the target the millennium development goals sector sanitation [13]. In Aprvous research, Gajah Putih river be a place emissions waste from activity for settlement and some plants, causing a decrease in the quality of water in the river [14]. In addition to the Gajah Putih river, the domestic waste water into the Pepe River still up of quality standard 
according to local regulations central java no. 5 2012, so that required planning the sewer and wastewater treatment domestic to prevent water pollution river by using land in border the river [12].

Onsite systems development plans divided into five stages. The first phase is targeting an improvement in healthy $86 \%$ of the toilets worked $100 \%$ in areas all over the city. Target customer sludge service regularly program reached $70 \%$ of the population of the city of Surakarta or 447,809 the soul of domestic sludge handling unit needs $250 \mathrm{~m}^{3} /$ day. At this stage of the need for improving the infrastructure, institutional, regulatory, community participation and dissemination Governments against the system. The second stage fourth, retained on site system remains on the design discharge $250 \mathrm{~m}^{3} /$ day.

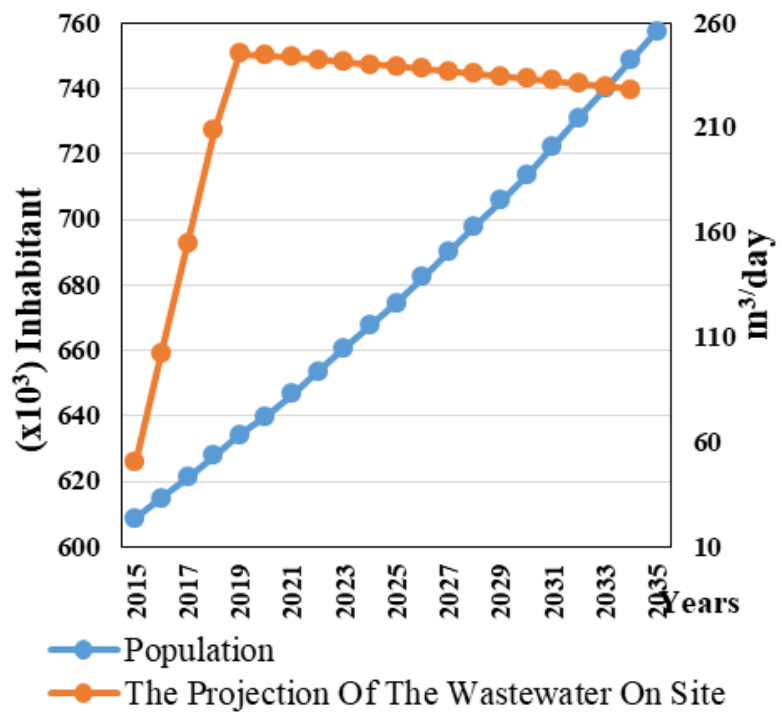

Service system determined from a map service areas of waste water city of Surakarta. When urban village serviced by the pipe waste water service means the area included in the recommendations priority off-site system, while areas have not passed by a pipe service included in on-site service system. Zone priority on site and off site can be seen in Table 1. Scope of priority zone off site is presented in Figure 3.

The shift from traditional, centralized, large sanitation infrastructure to alternative and distributed technologies is widely accepted as essential sustainable water management concept. The challenges facing urban water management, such as wastewater treatment technologies, models and assessment tools, the shift from traditional to more sustainable approaches remains slow significant needs advances in developing technical solutions. [8], [15]. Surakarta City will develop domestic sludge handling system onsite in every district. The proper location will be chosen to decrease distance transportation truck. Despite the land acquisition problem because the price and social conflict.

Opportunities manifest in areas where high resource recovery potentials from municipal wastewater and solid waste match their demand, such as the urban areas on Java. Projection in 2035, the resource recovery from this can supply significant fractions of the Indonesian demand for phosphorus (15\%), compost (35\%), duckweed (7\%), plastic (66\%), and paper (18\%) [16].

Development done by means of stages, despite the limited resources and the other needs also urged. Hence, there needs to be a priority areas services will be built. Several criteria that important but not included as the conditions for the city Surakarta relatively ramps and be mostly have had the system of waste off site. The overall health have data similar in every sub district and less visible to scoring.

Fig. 3 The Projection Of The Wastewater On Site

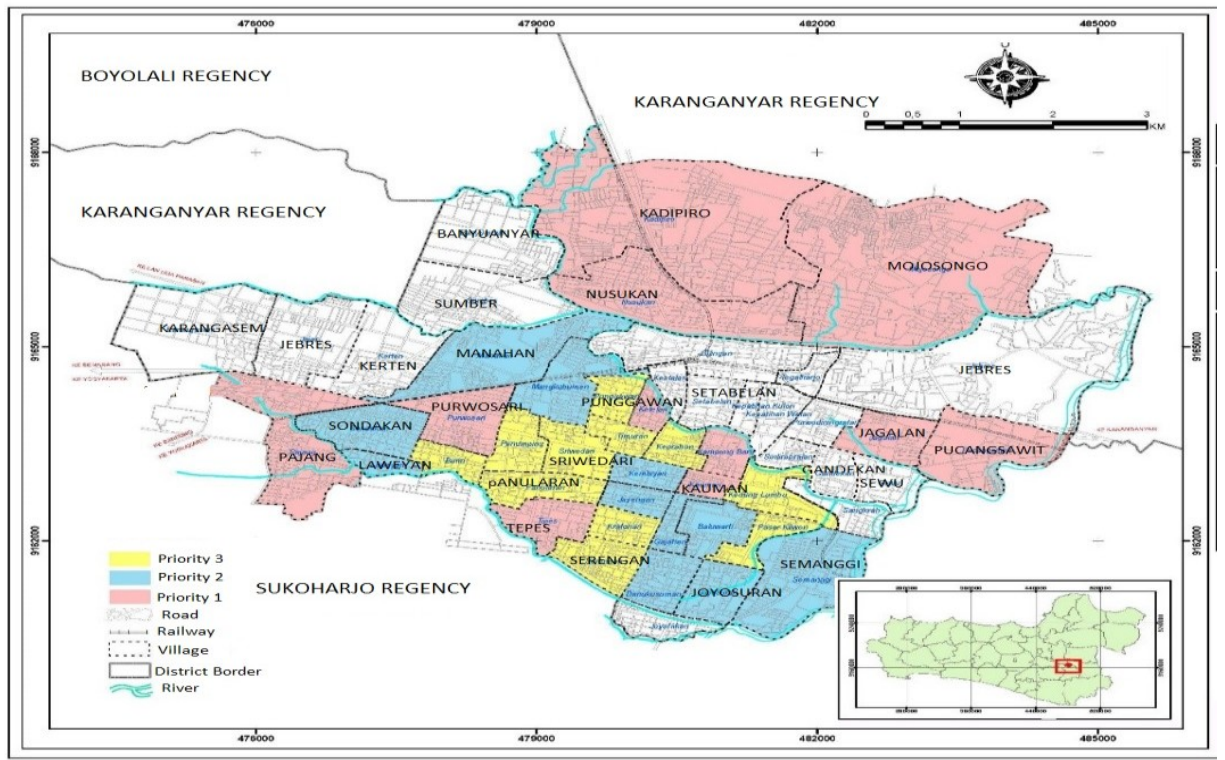

Fig. 4 Priority Zones Off Site

For stability in water work company that handle waste program, serious effort should be made by the top management to clearly identify organization visions and mission, objectives, past records. They should consider 
major strength and weakness and how handled it. What opportunities they have and how they utilized it and finally the threat and how they handled it [7].

Solo water work company have a job to handle sewerage treatment in there. One of the toughest challenges from outside is the lack public awareness of treating domestic waste. So, it makes low willingness to pay contribution. The financial of operating treatment plant and organization is deficit. The challenges from within are bad condition of infrastructure of sewer pipeline and lack of competence of employees.

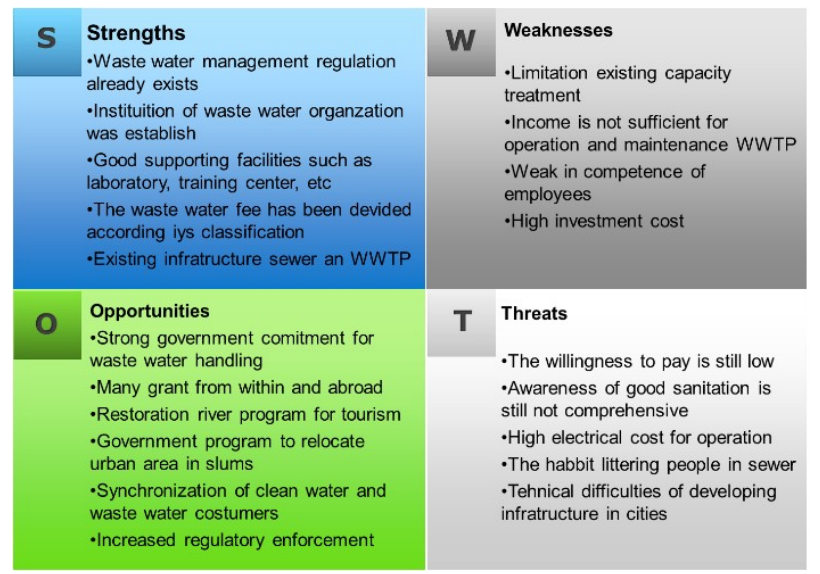

OPPORTUNITY

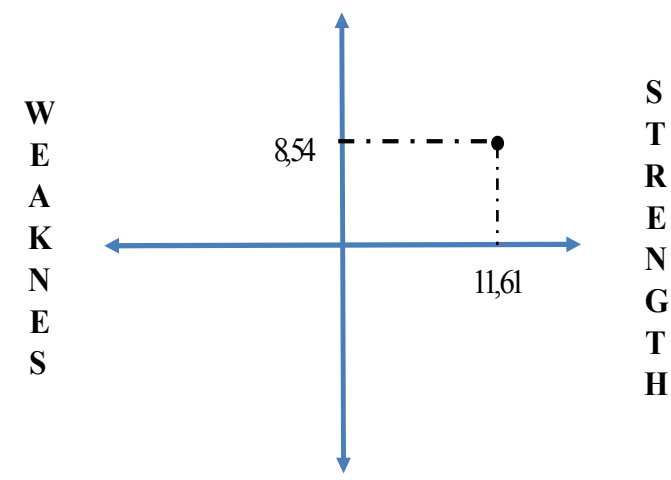

THREAT

Fig 5. SWOT Analys is Domestic Waste Water Organization on Surakarta City

Water Work of Surakarta City is currently in position III (Growth / Aggressive), aggressive, meaning the organization is in good condition and steady so it is possible to continue to expand, increase growth and achieve maximum progress. Thus the Water Work can harness the power it has to maximize available opportunities. It should be noted that in the internal aspect, the contributors of positive values are mostly because Water Work have excellent value in terms of corporate management, engineering and non-technical or financial systems and the company's operating system.

On the external side it is known that the main cause of more open opportunities than threats is due to several things. The good economic condition of the community certainly encourages high interest to subscribe to Water Work are the things that make the opportunity of
Surakarta City Water Work to expand its business quite open. Development urban water utilities are required to consider broad environmental impacts and water cycle interdependencies of water supply investments and yet quantitative assessments of broad impacts [17].

\section{Conclusion}

The establishment, domestic waste management systems that is Surakarta divided into two types of system on-site and system off site. Service system off site divided into 3 service areas which is stored on WWTP mojosongo, WWTP pucangsawit and WWTP Semanggi. While on-site system will are served by service programs Regular Cleaning Septictank. The target of waste water service the city of surakarta in the year 2035 is $41 \%$ system off site of $403 \mathrm{~L} / \mathrm{s}$ with 51.763 household and $59 \%$ system on site amounting to 250 $\mathrm{m}^{3} /$ day. Sanitation sustainable development is going to happen if supported by facility development also good, institutional development, the arrangement that oversees, and the public participation. Water Work of Surakarta City is currently in position rapid Growth that mean the organization is in good condition and steady so it is possible to continue to expand, increase growth and achieve maximum progress. The toughest challenge is how to increase community participation in waste management and improve the company's financial condition.

\section{Reference}

1. UN, "The Sustainable Development Goals Report," pp. 1-56, 2016.

2. R. I. Mcdonald et al., "Water on an urban planet: Urbanization and the reach of urban water infrastructure," vol. 27, pp. 96-105, 2014.

3. R. P. Lestari, "water sampling quality in Mojosongo water treatment plant," Surakarta, 2011.

4. L. Lam, K. Kurisu, and K. Hanaki, J. Clean. Prod., vol. 104, pp. 185-198, 2015.

5. S. M. Kerstens, I. Leusbrock, and G. Zeeman, Sci. Total Environ., vol. 530-531, pp. 53-65, 2015.

6. S. G. Board, Surakarta in numbers 2016. Surakarta: Statistic Goverment Board, 2017.

7. I. O. R. and N. J. Ifediora Christian Osita, "of Innovative and," Organ. Stab. Product. role SWOT Anal. an Acron. strength, weakness, Oppor. Threat, vol. 2, pp. 26-33, 2014.

8. S. Bell, "Renegotiating urban water," Prog. Plann., pp. 1-28, 2014.

9. S. Iacob, "The Wastewater - a Problem of Integrated Urban Water Management," Procedia Econ. an Financ., vol. 6, no. 13, pp. 436-443, 2013.

10. N. A. Phelps, T. Bunnell, M. A. Miller, and J. Taylor, Cities, vol. 39, pp. 37-49, 2014.

11. W. Astuti and D. A. Prasetyo, Procedia Environ. 
Sci., vol. 20, pp. 593-601, 2014.

12. R. Januarita, G. Samudro, S. Pepe, and A. L. Belakang, J. Tek. Lingkung., vol. 5, no. 4, 2016.

13. P. W. Ministry, Regulation of Public Work Ministry No: 16/PRT/M/2008 about strategy development domestic treatment system. Jakarta, 2008.

14. Y. K. Panjaitan, "Structure population Guppy fish (Poecilia Reticulata Peters) in Gajah Putih River Surakarta," Salatiga, 2016.
15. S. J. Van De Meene, R. R. Brown, and M. A. Farrelly. Glob. Environ. Chang., vol. 21, no. 3, pp. 1117-1127, 2011.

16. S. M. Kerstens, A. Priyanka, K. C. Van Dijk, F. J. De Ruijter, I. Leusbrock, and G. Zeeman. Resour. Conserv. Recycl., vol. 110, pp. 16-29, 2016.

17. J. M. Kandulu, J. D. Connor, and D. Hatton. J. Environ. Manage., vol. 145, pp. 43-53, 2014. 